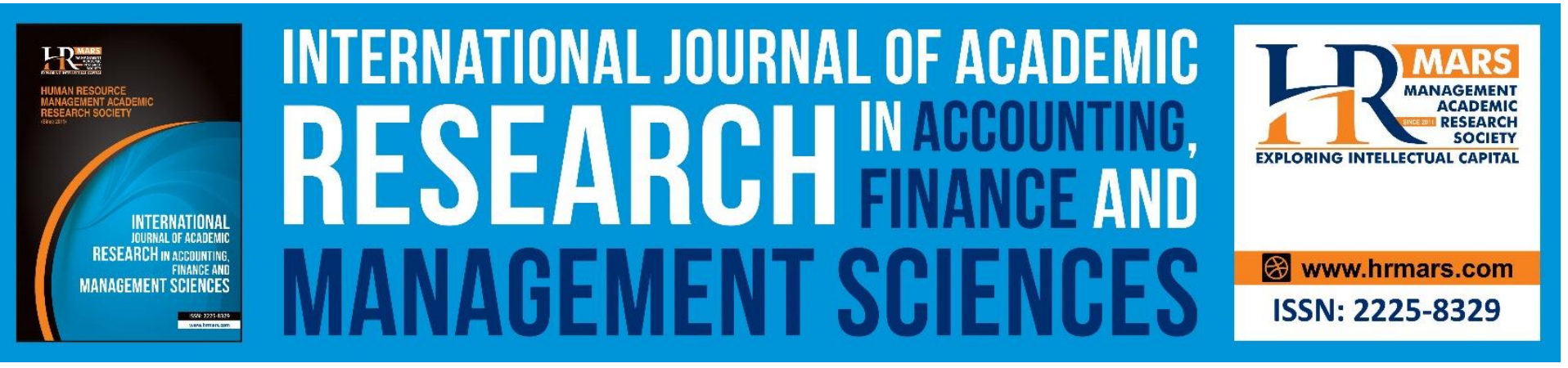

\title{
Corporate Financing Choice and Financial Performance of Banks in Nigeria: Return on Assets Measurement Approach
}

Osirim, Monday, Wadike, Chile George and Idatoru, Alapuberesika, Roberts

To Link this Article: http://dx.doi.org/10.6007/IJARAFMS/v10-i3/8031

DOI:10.6007/IJARAFMS/v10-i3/8031

Received: 18 July 2020, Revised: 29 July 2020, Accepted: 28 August 2020

Published Online: 27 September 2020

In-Text Citation: (Osirim, Wadike, \& Idatoru, 2020)

To Cite this Article: Osirim, M., Wadike, C. G., and Idatoru, A. R. (2020). Corporate Financing Choice and Financial Performance of Banks in Nigeria: Return on Assets Measurement Approach. International Journal of Academic Research in Accounting, Finance and Management Sciences. 10(3), 309-324.

\section{Copyright: (c) 2020 The Author(s)}

Published by Human Resource Management Academic Research Society (www.hrmars.com)

This article is published under the Creative Commons Attribution (CC BY 4.0) license. Anyone may reproduce, distribute, translate and create derivative works of this article (for both commercial and non-commercial purposes), subject to full attribution to the original publication and authors. The full terms of this license may be seen at: http://creativecommons.org/licences/by/4.0/legalcode

Vol. 10, No. 3, 2020, Pg. 309 - 324

Full Terms \& Conditions of access and use can be found at http://hrmars.com/index.php/pages/detail/publication-ethics 


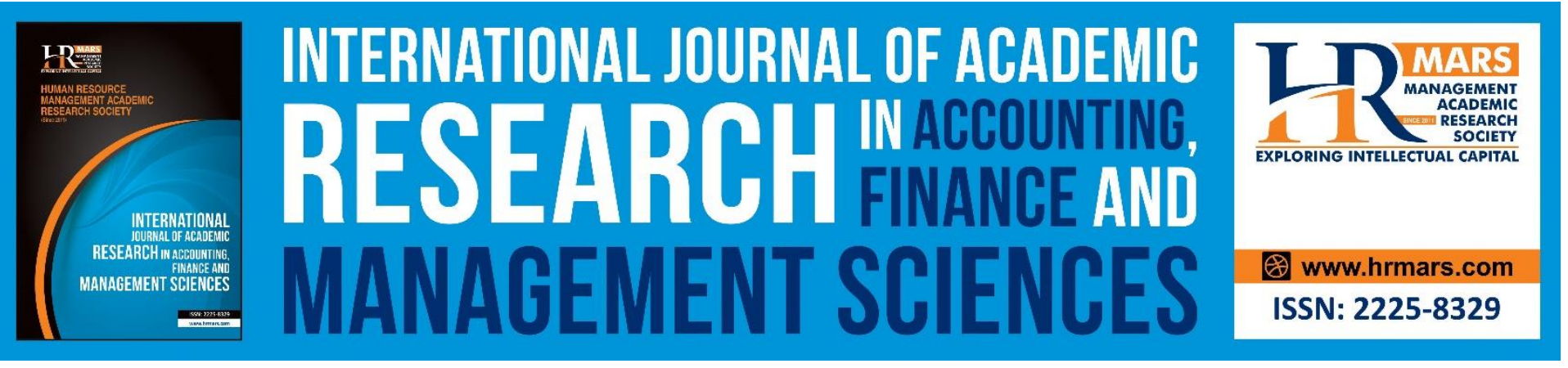

\title{
Corporate Financing Choice and Financial Performance of Banks in Nigeria: Return on Assets Measurement Approach
}

\author{
Osirim, Monday ${ }^{1}$, Wadike, Chile George ${ }^{2}$ and Idatoru, \\ Alapuberesika, Roberts ${ }^{3}$ \\ Department of Accounting, Ken Sarowiwa Polytechnic, Bori, Nigeria \\ Email: osirim2000@yahoo.com
}

\begin{abstract}
This study is focused on providing empirical evidence on the relationship between corporate financing choice and financial performance of listed Nigerian banks from 2010 to 2016. The objective is to ascertain the effect of corporate financing choice on financial performance of banks in Nigeria by using equity and leverage financing as predictor variables and return on assets (ROA) as a criterion variable. To meet the objective of this study, secondary data obtained from the annual reports and account of Eight (8) selected banks were utilized and analyzed using multiple regressions (OLS) statistical tool. The results of the analysis show that leverage financing (LF) is not statistically significant at 0.05 ( $5 \%$ confidence level). In addition, the study shows that there is a positive relationship between equity financing and financial performance of banks; however the relationship is not significant as $p$-value of $0.879>0.05$. This suggests that a percentage increase in equity leaving debt constant will positively increase return on assets (financial performance) of quoted banks in Nigeria but not significantly. Based on this, it was recommended that to improve the financial performance of banks in Nigeria cum return on asset, optimization of the corporate financing mix (debt and equity) should be prioritized. Quoted banks in Nigeria should moderate the choice of leverage financing in favour of more equity financing to improve earnings capacity and to maximize shareholders' wealth.
\end{abstract}

Keywords: Corporate Financing, Return On Asset, Debt Financing, Equity Financing, Leverage

\section{Introduction}

Decision-making is a daily task that both individuals and corporate entities cannot circumvent. There are many decision areas in an enterprise and paramount among them is corporate financing decision. The choice of whether to finance a corporate entity with equity or debt instruments or a combination of the two to maximize corporate value is a herculean task as it entails making decision between the choice of debt or equity financing in a balanced proportion and factoring into the selection process the costs and benefits. In making financing choice, the management is concerned with the 
determination of the best financing mix that would yield the best result for the firm. Therefore, corporate financing choice involves making decisions between using debt and equity to finance the business to maximize return as well as to increase firms' value. It extends to the maturity (short or long term) and priority structure as to whether it should be secured or not. Corporate financing decision is imperative for any corporate entity because of the need to maximize return to the equity holders and other relevant stakeholders. In addition, such financing choice has a great impact on the firms' ability to deal with the dynamic world of business and to remain competitive (Awunyo \& Badu, 2012).

The choice of either debt or equity or a mix of the two is important as it may affect the financial variables such as return on assets and sales growth of the company. Financing choice can also improve or threaten the going concern of a corporate entity. A right choice may culminate in high return and increase in market value of the entity. However, a haphazard, not well thought-out and planned choice of financing might threaten the going concern and survival of the business. These problems have given rise to the postulations geared towards the determination of the optimal capital structure. There is a consensus in most of the empirical literature that leverage increases with the size of the firm, noncurrent assets, non-debt tax benefits and growth options, which are some of the specific attributes of corporate entities that determine leverage ratios. On the other hand, leverage reduces with economic fluctuation, the likelihood of liquidation, profitability and efficiency of operations. It also affects excellent product, promotion expenses, corporate social responsibility cost, research and development costs among others.

Barclay and Smith (2005) asserts that large amount of leverage can negatively affect the market value of the firm leading to business failure. They also noted that over investment might be detrimental to the growth and sustainability of the company and too little leverage can lead to underinvestment. It therefore becomes reasonable, appropriate and imperative to make the right financing choice that will ultimately maximize the firms' overall market value.

Operations of corporate entities are guided by well-articulated financial policies and capital structure is one of the most critical financial policies of firms. The choice to make and the decision to take borders on whether to finance the entity using debt or equity. The corollary choices if debt financing is selected are the choice of debt level, the maturity structure, and the types of restrictive pact in the indentations. The special characteristics, nature and environment of operation are some of the deterministic factor in making these financial policy choices. The choice of debt financing requires a trade-off between the costs of procuring and servicing the debts and the benefits derivable thereof. The choice of leverage financing especially for growth companies may lead to a conflict of interest between shareholders, lenders or bondholders.

In the works of Jensen and Meckling (1976); Myers (1977), and Smith and Warner (1979), it was argued that the suboptimal incentive effects of debt financing could be controlled by variety of contracting mechanisms, including the use of short-term debt and restrictive binding agreements. It has been suggested overtime that firms need to use less amount of debt financing in their operation as this will reduce conflict of interest between the equity holders and debenture holders. 
The financing mix of corporate entities is not a new concept. However, the question of how financing policy choices affect the overall performance of firms has not been fully answered. Corporate financing choices vary with firms' characteristics, and especially firms with growth opportunities. There are several empirical literatures on corporate financing decision especially in the developed economies and a few in emerging and less advanced economies. The lack of agreement among researchers on the impact of corporate financing on firm's value/ financial performance especially in a developing economy as Nigeria informed this research.

The rest of the paper is structured as follows: In section 2, equity and leverage financing are conceptualized and relevant theories underpinning corporate financing are summarized. In section 3 , prior empirical findings of corporate financing and firms' performance are reviewed. The empirical evidence of this work and the underlying methodology are provided in Section 4 while Section 5 is concerned with the results and discussion of findings, and lastly, in section 7, conclusion and recommendations are provided.

\section{Conceptual Review}

\section{Equity and Leverage Financing}

Key corporate funding sources consist of equity and debt/leverage financing. Equity finance is the original capital invested in exchange for shares of ownership in the enterprise plus any surpluses of income over expenditure. Pandey (1999) asserts that equity finance include share-capital, share premium, reserves and retained earnings of an entity. The cost of equity financing of an entity using the dividend growth criteria can be expressed with little modifications as:

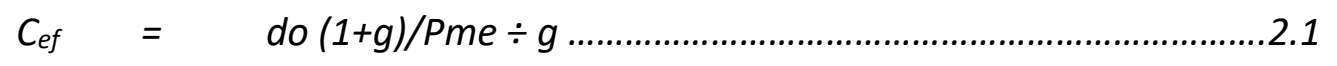

Where

$\mathrm{C}_{\mathrm{ef}} \quad=$ cost of equity financing;

Do, = current dividend per share;

Pme, = the ex-dividend market price per share and

g. $=$ the expected constant annual growth rate in earnings and dividend per share

\section{Leverage Financing}

Leverage financing consists of debts/loans utilized in financing an entity's investment. Fama and French (1997) define leverage as total liabilities to total assets of an organization. The cost of leverage financing can be expressed as:

$$
\begin{aligned}
& C_{L}=\operatorname{lnt} / \mathrm{Lo} \\
& \text { Where:: } \\
& C_{l}=\text { cost of leverage before tax; } \\
& \text { Int, = the interest element and } \\
& \text { Lo, = issue price of leverage }
\end{aligned}
$$

The cost of leverage financing after tax can be expressed as: 
$C_{l}(1-T)$ 2.1.1.

Where:

$T$ is corporate income tax rate.

Bradley, et al. (1984) opine that firms with large investment in non-current assets are likely to have a higher financial leverage since they borrow at lower interest rates if their debt is secured with such assets and other collaterals. Corporate financing is synonymous with capital structure. It is the proportion of financial resources (leverage or equity) attributed to the firm through internal and external finances. The means and choice of corporate financing has important implications on firms' financial performance. The aggregate effect of these discrete corporate financing choices are what capital structure typifies and this has long been a focus of research in the corporate finance discipline mostly in the developed economy. The use of loans and other debts instrument can increase the investment level of a corporate entity and a minimum profit margin is imperative in order to meet the obligation of preference shareholders and other fixed interest expense. However, loans and advances increase the risk exposure of corporate entities. Both the shareholders and the debenture holders have different claim on the assets and returns of the firm. Thus, corporate financing composition (leverage-equity mix) can take any of the following forms depending on the nature and characteristics of the entity:

\begin{tabular}{|c|c|c|}
\hline Equity composition & Leverage composition & Explanation \\
\hline Equity - 100\% & Leverage - $0 \%$ & \multirow{8}{*}{$\begin{array}{l}\text { Unlevered company } \\
\text { Levered company (scarce as most } \\
\text { firms have mix of equity financing) } \\
\text { More equity capital } \\
\text { High proportion of debt financing } \\
\text { Equal proportion of financing mix } \\
\text { Combines certain \% of equity and } \\
\text { leverage }\end{array}$} \\
\hline Equity - $0 \%$ & Leverage - $100 \%$ & \\
\hline & & \\
\hline Equity - $60 \%$ & Leverage - $40 \%$ & \\
\hline Equity - $40 \%$ & Leverage - $60 \%$ & \\
\hline Equity - 50\% & Leverage - $50 \%$ & \\
\hline Equity- $x \%$ & Leverage - $\mathrm{x} \%$ & \\
\hline & & \\
\hline
\end{tabular}

Corporate entities may opt for increase in debt financing when weak operating performance reduces equity value or make it imperative to opt for external financing through debt instruments. If there is an economically important optimal capital structure, then firms that deviate too far from the optimum will face greater risk of failure or acquisition (Chung, et al, 2013). 


\title{
Conceptual Framework
}

\section{PREDICTOR VARIABLE}

\author{
Equity Financing
}

Leverage Finacing

\section{CRITERION VARIABLE}

\author{
Return on Assets (ROA)
}

\section{Theoretical Review}

\section{Theories of Corporate Financing}

The three fundamental theories underlining corporate financing are the trade-off theory, the pecking order theory and the contract cost theory. These theories are discussed sequentially as follows:

\section{Trade-off theory}

The trade-off theory is hinged on two broad assumptions: The financial distress costs and agency costs. The theory states that there is a trade-off between financial distress costs and agency costs as firms tend to borrow to the point where the tax savings from an additional amount borrowed are equal to the costs that may result from the increased probability of liquidation. The theory rationalizes moderate leverage ratios as firms are viewed as setting a target debt to equity ratio and gradually move towards it to create corporate value and to increase financial performance. It suggests that taxes, bankruptcy costs and agency costs integrate to produce an optimal best capital structure and corporate entities may suffer for changing from the optimum level through financial distress. The theory emphasizes taxes and some form of optimal capital structure that can maximize the firms' return.

\section{Pecking Order Theory}

This is an alternative to the trade-off theory. The theory emphasizes on asymmetric (differences/variation) in information. The theory forecast the choice of management financing their business with internally generated fund and prefers debt to equity when there is need to finance the company with external fund. The pecking order theory of corporate financing suggests that improved returns on assets/equity (profitability) of firms are primarily from internal corporate financing from 
retimed earnings rather than leverage financing. This means that corporate entities with greater profit rates will have less amount of leverage (Myers \& Majluf, 1984).Titman and Wessel (1988) agree that profitable corporate entities would maintain relatively lower proportion of leverage since they have the capacity to generate internal funds from retained income.

\section{The Contract Cost Theory}

Fama (1990) proposes the contract cost theory and uses the cost of writing and executing contract among agents (contract costs) to explain the predominance of debt-equity financial contracts and the use of leverage instruments in a corporate financing. He states that corporate entities have a mixture of debt and equity in their capital structure because of incentives to lower contract costs. Besides, he argues that by placing debt instruments in the context of the overall contract structure of a firm, the capital structures are best analyzed in the context of the overall contract structures of firms [Fama, 1990]. The main idea behind the contract-cost theory is that for any entity to succeed in a competitive world of business, it must device a means to reduce contract costs of claim holders. The implication of this theory lies on the fact that it provides a fairly general and consistent theoretical framework, which can explain debt-equity mix and dimensions of firms' corporate financing such as the maturity and priority structures of loans, bonds and other debts. The theory is a new approach to the theories of optimal corporate financing and empirical evidence is in support of it. The theory is relevant to corporate financing decisions as it implies a specific linkage between optimal contract structure and capital financing choice that are influenced by contract costs and corporate financing choice.

\section{Empirical Review}

There are several existing empirical evidences on capital structure but much work has not been carried out on corporate financing and financial performance of financial services companies in Nigeria. In addition, most of the researches lack consensus in their results. Sheik \& Wang (2011) investigates the determinants of capital structure in Pakistan manufacturing industry and confirm that the explanatory variables, which are profitability, liquidity and earnings volatility, are negatively correlated to the criterion variable, which is debt ratio. However, firm size is found to be positively associated with the debt ratio.

Bauer (2004) investigates the influence of non-debt tax benefits, firm size, profitability, volatility, tangibility and industry classification on corporate financing. Findings reveal that there is a positive linkage between leverage and firm size and tax while there exist negative relationship between corporate financing (leverage) with profitability, tangibility (asset structure), growth opportunities and non-debt tax shields. The study shows that there was to correlation between leverage and volatility. The negative relationship between corporate financing and growth options implies that corporate entities with greater future growth opportunities should make choice in respect to the use of more equity funding as against leverage.

Rajan and Zingales (1995) investigated the relationship between growth opportunities and leverage and find that leverage is negatively related to growth opportunities, while Barclay and Smith (2005) find that debt maturity is negatively related to growth opportunities. Saeed et al (2013) employed 
the annual reports of quoted banks in Pakistan between 2007 to 2011 to measure the influence of capital structure on performance of banks in Pakistan. Their findings reveal that a positive relationship exist between long-term debt to capital ratio, short term debt to capital ratio and total debt to capital ratio (proxies for capital structure) and return on assets, return on equity and earnings per shares (proxies for banks performance). Johnson (2003) estimates systems of simultaneous equations that treat leverage and debt maturity as jointly endogenous variables using compute stat data. The research confirms that leverage and debt maturity are negatively related to growth opportunities.

Jensen and Meckling (1976); Myers (1977) argue that there will be potential loss in corporate value when managers' made suboptimal choices to maximize returns on equity value in the face of accrued risky debt rather than the total firm value. Such investment decisions as regards leverage and growth opportunities will afford managers the opportunity to either make excess or lower investment in future growth opportunities. It has been advocated that the ratio of debt in entities with high growth opportunism should be kept at minimal level. Childs, et al (2005) predicted that entities with more growth options should have a higher ratio of short-term debt financing as it can reduce both under and over investments. However, Diamond (1991) argues that short-term debt exposes the firm to a liquidity risk of refunding the short-term loan or advances and the threat of liquidation.

Adopting data covering from 1974-1982 in their research in the United States, Titman and Wessels (1988) reveal that there is a negative association between dimensions of financial performance and leverage (level of debt). Zeitun and Tian (2007) investigated 167 listed Jordanian firms for the period 1989-2003.They employ return on assets, return on equity, earnings before interest and tax plus depreciation to total assets as accounting measures. They found evidence that short-term debt reduces a firm's performance. This suggests that there exist a significant negative association between financing choices using short-term debt and firms' performance.

Onaolapo and Kajola (2010) suggest that debt ratio has a significant negative impact on firms' financial performance measures (return on asset and return on equity). Similar to this, Omondi and Muturi (2013) investigated 29 firms operating at the Nairobi Securities Exchange during the period 2006-2012. The study suggests that leverage (ratio of debt-equity) has a significant negative effect on financial performance (ROA). The study also provides evidence to infer that liquidity (current assets over current liabilities) play a vital role in improving the firm's financial performance. Based on the research findings, the study concluded that company size has a significant positive effect on financial performance. Hall (2004) investigated the determinants of the capital structure of European SMSs and his findings suggest negative relationships between profitability and both long-term debt and short-term debt ratios.

Empirical evidence from previous studies seems to be consistent with the pecking order theory and the work of Booth (2001); Chen (2004) who find a negative relationship between leverage ratios and profitability. On the strength of the above literature review, the following testable hypotheses on the influence of corporate financing on financial performance of banks in Nigeria are postulated: 
$\mathrm{H}_{\mathrm{o1}}$ : There is no significant positive relationship between corporate leverage financing and returns on assets of quoted banks in Nigeria.

$\mathrm{H}_{\mathbf{0 2}}$ : There is no significant positive relationship between corporate equity financing choice and returns on asset of quoted banks in Nigeria.

The proposition in $\mathrm{Ho}_{1}$ above implies that there exist a negative relationship between leverage and banks' financial performance. Thus, it is expected that leverage level of Nigerian commercial banks is significantly negatively related to the profitability.

\section{Methodology}

Secondary data on annual reports of 8 sampled quoted banks in Nigeria were gathered from 2011 to 2015 to examine the determinants of corporate financing choice for Eight (8) quoted banks in Nigeria out of the 16 listed firms at the time of this study. Based on the research objective, variables employed and their proxies are adopted from existing work, hence the expo facto research design was used. The explained (criterion) variable is return on assets and the explanatory variables include debt (leverage) financing and equity financing.

Table 1: Definition of variables

Variables

Definition

\section{Explained/criterion variable:}

Return on asset ratio

Explained (predictor) variables:

Leverage financing

Ratio of total debt (liabilities) to total assets

Equity financing

Book value of total liabilities (debt) divided by book value of total assets

Book value of total equity divided by the book value of total assets

\section{Ordinary Least Square (OLS) model}

$\mathrm{ROA}_{i \mathrm{t}}=\beta_{0}+\beta_{1} \mathrm{~L}_{\mathrm{FCit}}+\beta 2 \mathrm{E}_{\mathrm{FCit}}+\mu_{\mathrm{it}}$

Where:

$\mathrm{ROA}_{\mathrm{it}}=$ return on assets of bank $\mathrm{i}$ at time $\mathrm{t}$

$\mathrm{L}_{\mathrm{FCit}} \quad=\quad$ leverage financing choice of bank $\mathrm{i}$ at time $\mathrm{t}$

$\mathrm{E}_{\mathrm{FC} i \mathrm{it}} \quad=\quad$ equity financing choice of bank $\mathrm{i}$ at time $\mathrm{t}$

$\beta 0=$ common $y$-intercept

$\beta_{1}-\beta_{2}=$ coefficient of the relevant predictor variables

$\mu_{\text {it }} \quad=\quad$ stochastic error terms of bank $\mathrm{i}$ at time $\mathrm{t}$

\section{Analysis and Findings}


INTERNATIONAL JOURNAL OF ACADEMIC RESEARCH IN ACCOUNTING, FINANCE AND MANAGEMENT SCIENCES

Vol. 10 , No. 3, 2020, E-ISSN: 2225-8329 @ 2020 HRMARS

Table 5.1 Descriptive Statistics

Residuals Statistics ${ }^{a}$

\begin{tabular}{|l|r|r|r|r|}
\hline & \multicolumn{1}{|c|}{ Minimum } & Maximum & \multicolumn{1}{c|}{ Mean } & \multicolumn{1}{c|}{ Std. Deviation } \\
\hline Predicted Value & .0191 & .0573 & .0268 & .01249 \\
Residual & -.06034 & .16949 & .00000 & .03524 \\
Std. Predicted Value & -.617 & 2.444 & .000 & 1.000 \\
Std. Residual & -1.661 & 4.666 & .000 & .970 \\
\hline
\end{tabular}

a. Dependent Variable: ROA

Table 5.2 : Descriptive Statistics2

\begin{tabular}{|l|r|r|r|}
\hline & \multicolumn{1}{|c|}{ Mean } & Std. Deviation & $\mathrm{N}$ \\
\hline ROA & .0268 & .03739 & 35 \\
Leverage & .7302 & .29766 & 35 \\
Equity & .2624 & .30054 & 35 \\
\hline
\end{tabular}

The descriptive analysis of the variables adopted in the research shows that return on asset which is a dimension of financial performance of the banks has an average return of 0.0268 (N0.0268) with a standard deviation of 0.03739 . Leverage financing averaged 0.7302 with a standard deviation of 0.29766 . Equity averaged 0.2624 with a standard deviation of 0.30054 . Aggregate observations are 35.

Table 5.3 Correlations

\begin{tabular}{|ll|r|r|r|}
\hline & & \multicolumn{1}{|c|}{ ROA } & \multicolumn{1}{c|}{ Leverage } & \multicolumn{1}{c|}{ Equity } \\
\hline \multirow{2}{*}{ Pearson } & ROA & 1.000 & -.333 & .334 \\
Correlation & Leverage & -.333 & 1.000 & -.993 \\
& Equity & .334 & -.993 & 1.000 \\
Sig. & ROA &. & .025 & .025 \\
& Leverage & .025 & .000 \\
& Equity & .025 & .000 & .00 \\
$\mathrm{~N}$ & ROA & 35 & 35 & 35 \\
& Leverage & 35 & 35 & 35 \\
& Equity & 35 & 35 & 35 \\
\hline
\end{tabular}

Table 5.3 above shows that the correlation between return on asset and leverage is weak and negative at $-0.333(-0.333 \%)$. The correlation between return on asset and equity is however weak but positive at $0.334(33 \%)$. 
INTERNATIONAL JOURNAL OF ACADEMIC RESEARCH IN ACCOUNTING, FINANCE AND MANAGEMENT SCIENCES

Vol. 10 , No. 3, 2020, E-ISSN: 2225-8329 @ 2020 HRMARS

Table 5.4 : Regression Coefficients

\begin{tabular}{|c|c|c|c|c|c|c|c|c|}
\hline \multirow{2}{*}{\multicolumn{2}{|c|}{ Model }} & \multicolumn{2}{|c|}{$\begin{array}{l}\text { Unstandardized } \\
\text { Coefficients }\end{array}$} & \multirow{2}{*}{$\begin{array}{c}\text { Standardized } \\
\text { Coefficients } \\
\text { Beta }\end{array}$} & \multirow[t]{2}{*}{$\mathrm{T}$} & \multirow[t]{2}{*}{ Sig. } & \multicolumn{2}{|c|}{$\begin{array}{c}95.0 \% \\
\text { Confidence } \\
\text { Interval for B }\end{array}$} \\
\hline & & B & $\begin{array}{l}\text { Std. } \\
\text { Error }\end{array}$ & & & & $\begin{array}{l}\text { Lower } \\
\text { Bound }\end{array}$ & $\begin{array}{l}\text { Upper } \\
\text { Bound }\end{array}$ \\
\hline & (Constant) & 0.03 & 0.178 & & 0.17 & 0.866 & -0.332 & 0.393 \\
\hline & Leverage & -0.015 & 0.18 & -0.116 & -0.081 & 0.936 & -0.381 & 0.352 \\
\hline 1 & Equity & 0.027 & 0.178 & 0.219 & 0.153 & 0.879 & -0.335 & 0.39 \\
\hline
\end{tabular}

a. Dependent Variable: ROA

The ordinary least square model of the studied variables: leverage financing, equity financing and return on assets can be modeled in a regression function as given below:

$\mathrm{ROA}=0.03-0.015 \mathrm{LF}+0.027 \mathrm{EF}$

\begin{tabular}{|c|c|c|c|c|c|c|c|c|}
\hline \multicolumn{9}{|c|}{ Model Summary } \\
\hline \multirow{2}{*}{$\begin{array}{l}\text { Mode } \\
\text { I }\end{array}$} & \multirow[t]{2}{*}{$\mathrm{R}$} & \multirow{2}{*}{$\begin{array}{c}\text { R } \\
\text { Square }\end{array}$} & \multirow{2}{*}{$\begin{array}{l}\text { Adjusted } \\
\text { R Square }\end{array}$} & \multirow{2}{*}{$\begin{array}{l}\text { Std. Error } \\
\text { of the } \\
\text { Estimate }\end{array}$} & \multicolumn{3}{|c|}{ Change Statistics } & \multirow{2}{*}{$\begin{array}{l}\text { Durbin- } \\
\text { Watson }\end{array}$} \\
\hline & & & & & $\begin{array}{c}\text { R Square } \\
\text { Change }\end{array}$ & $\begin{array}{c}\text { F } \\
\text { Change }\end{array}$ & $\begin{array}{c}\text { Sig. F } \\
\text { Change }\end{array}$ & \\
\hline 1 & $\begin{array}{r}.334 \\
a\end{array}$ & 0.112 & 0.056 & 0.03633 & 0.112 & 2.011 & 0.15 & 2.17 \\
\hline
\end{tabular}

a. Predictors: (Constant), Equity, Leverage

b. Dependent Variable: ROA

The correlation coefficient is $0.334(33 \%)$ and the correlation of determination R2 of the regression is $0.112(11 \%)$. This means that $11 \%$ of changes in return on asset is explained by the derived regression equation. The Durbin Watson value of 2.17 indicates the absence of auto correlation within the values of the variables.

\section{Conclusion and Recommendations}

The study investigated the influence of corporate financing choice on the return on assets of banks in Nigeria. The statistical models explicitly incorporated leverage and equity as variables of corporate financing choice and financial performance of banks was proxied by return on assets. Findings indicate that leverage financing (LF) is not statistically significant at 0.05 ( $5 \%$ confidence level). By this, the null hypothesis is accepted. Thus, there is no significant positive relationship between corporate leverage financing and return on assets of quoted banks in Nigeria. This means that a percentage increase in leverage leaving equity financing constant, will not bring about improvement in the financial performance of quoted banks in Nigeria. In addition, equity financing is not statistically significant but it is positive. This implies that there is a positive relationship between banks equity financing and financial performance of banks but the relationship is not significant as $p$-value of 0.879 
$>0.05$. This suggests that a percentage increase in equity leaving debt constant will increase return on assets (financial performance) of quoted banks in Nigeria but not significantly. We therefore conclude that there is no significant relationship between corporate equity financing choice and returns on asset of quoted banks in Nigeria. These findings agree with Bauer (2004) who found a negative relationship between corporate financing and growth options. He suggested that corporate entities with greater future growth opportunities should make choice in respect to the use of more equity funding as against leverage. Furthermore, the empirical evidence is consistent with the pecking order theory and the evidence found by Friend and Lang, (1988); Hall (2004) Titman and Wessel (1988), Rajan and Zingales (1995), Booth (2001) and Chen (2004), who reported a negative relationship between profitability and capital structure/financing choice.

On the bases of these findings, it is recommended that quoted Nigerian banks should consider the increase use of equity financing to improve the return on assets and the overall earnings capacity of the banks. In other words, they should moderate the use of leverage financing as this study reveals that it has a negative relationship with banks performance. High levels of gearing may lead to liquidation if the benefitting banks could not make payment on their debt. Besides, existing and prospective investors and creditors of Nigerian quoted banks should evaluate their corporate financing policies and strategies before committing their resources in form of investment into such entities as the strength of the financing mix of a bank could determine its corporate value and earnings capacity.

\section{References}

Awunyo, D. V., \& Badu, J. (2012). Capital structure and performance of listed banks in Ghana, Global Journal of Human Social Science, 12(1).

Barclay, M. J., \& Smith, C. W. (2005). The capital structure puzzle: another look at the evidence in Chaw, D. H. (n.d). The New Finance: Where theory meet practice. New York McGraw- Hill. Bauer, P. (2004). Determinants of capital structure: empirical evidence from Czech Republic, Journal of Economics and Finance, 54, 1-21.

Booth, L., Aivazian, V., Demirgue-Kunt, A., \& MaKSimovic, V. (2001). Capital structure in developing countries, The Journal of Finance, 56(1), 87-130

Bradley, M., Jarrell, G. A., \& Kim, E. H. (1984). On the existence of an optimal capital structure: theory and evidence. Journal of Finance 39, 857-878.

Chen, C. K. (2004), Reserve on impacts of team leadership on team effectiveness. The Journal of American Academy of Business, Cambridge, 266-278.

Childs, P. D., David, C. M., \& Steven, H. (2005). Interactions of corporate financing and investment decisions: The effects of agency conflicts, Journal of Financial Economics, 76, 667-690.

Diamond, D. W. (1991). Financial intermediation and delegated monitoring. Review of Economic Studies, 51, 393-414.

Fama, E. F. (1990). Contract costs and financing decisions of firms. Journal of Business, 63, 871-S91.

Fama, E. F., \& French, K. R. (1997). Industry costs of equity. Journal of Financial Economics, 43, 153-197. 
Fama, E. F., \& Michael, C. J. (1983). Agency problems and residual claims. Journal of Law and Economics, 26, 327-349.

Fama, E. F., \& Merton, H. M. (1972). The Theory of Finance. NewYork, NY: Holt, Rinehart, and Winston.

Friend, I., \& Larry-Lang, H. P. (1988). An empirical trust of the impact of managerial staff- interest on co-operate capital structure, Journal of Finance, 43; 271-281.

Hall, G., Hutchinson, P.. \& Michealas, N. (2004). Determinants of the capital structure of European SMSs, Journal of Business Finance and Accounting. 31(50), 711-728.

Jensen, M. C., \& Meckling, W. H. (1976), Theory of the firm: managerial behavior, agency costs and ownership structure." Journal of Financial Economics, 3, 305-360.

Johnson, S. A. (2003). Debt maturity and the effects of growth opportunities and liquidity risk on leverage, Review of Financial Studies, 16 (1), 209-236.

Myers, S. C., \& Majluf, N. S. (1984). Corporate financing and investment decisions: when firms have information that investors do not have. Journal of Financial Economics, 13,187221.

Myers, S. C. (1977). Determinants of corporate borrowing, Journal of Financial Economics 5, 147175.

Omondi, M., \& Muturi, W. (2013). Factors affecting the financial performance of listed companies at the Nairobi Securities Exchange in Kenya. Research Journal of Finance and Accounting, 4(15), 99-104.

Onaolapo, A., \& Kajola, S. (2010). Capital structure and firms performance: Evidence from Nigeria. European Journal of Economics, Finance and Administrative Sciences, 25, 70-

Pandey, I. M. (1999). Financial Management, (8 $8^{\text {th }}$ ed.), New Delhi India, Vikas.

Rajan, R. G., \& Zingales, L. (1995). What do we really know about capital structure? Some evidence from international data, Journal of Finance 50, 1421-1460.

Saeed, M. M., Gull, A. A., \& Rasheed, M. Y. (2013). Impact of capital structure on banking performance: a case study of Pakistan, Interdisciplinary Journal of Contemporary Research in Business, 5 (10) 393-403.

Smith, C. W., Jr., \& Warner, J. B. (1979a). On financial contracting: An analysis of bond covenants. Journal of Financial Economics, 7, 117-161.

Smith, C. W., Jr., \& Warner, J.B. (1979b). Bankruptcy, secured debt, and optimal capital structure: comment. Journal of Finance, 34, 247-251.

Titman, S., \& Wessels, R. (1998). The determinants of capital structure, Journal of Finance, 43 (1): 1-19. 
INTERNATIONAL JOURNAL OF ACADEMIC RESEARCH IN ACCOUNTING, FINANCE AND MANAGEMENT SCIENCES

Vol. 10 , No. 3, 2020, E-ISSN: 2225-8329 @ 2020 HRMARS

\section{Appendixes}

Table 1

ANOVA $^{\mathrm{a}}$

\begin{tabular}{|rl|r|r|r|r|r|}
\hline Model & Sum of Squares & $\mathrm{df}$ & $\begin{array}{c}\text { Mean } \\
\text { Square }\end{array}$ & $\mathrm{F}$ & Sig. \\
\hline \multirow{2}{*}{1} & Regression & .005 & 2 & .003 & 2.011 & $.150^{\mathrm{b}}$ \\
& Residual & .042 & 32 & .001 & & \\
& Total & .048 & 34 & & & \\
\hline
\end{tabular}

a. Criterion Variable: ROA

b. Predictors: (Constant), Equity, Leverage

Table 2

Coefficient Correlations $^{a}$

\begin{tabular}{|rll|r|r|}
\hline Model & & \multicolumn{1}{|c|}{ Equity } & \multicolumn{1}{c|}{ Leverage } \\
\hline \multirow{4}{*}{1} & \multirow{2}{*}{ Correlations } & Equity finance & 1.000 & .993 \\
& & Leverage finance & .993 & 1.000 \\
& \multirow{3}{*}{ Covariance } & Equity finance & .032 & .032 \\
& & Leverage finance & .032 & .032 \\
\hline
\end{tabular}

\section{Table 3}

Collinearity Diagnostics ${ }^{a}$

\begin{tabular}{|c|c|c|c|c|c|c|}
\hline \multirow{2}{*}{\multicolumn{2}{|c|}{ Model Dimension }} & \multirow[t]{2}{*}{ Eigenvalue } & \multirow{2}{*}{$\begin{array}{l}\text { Condition } \\
\text { Index }\end{array}$} & \multicolumn{3}{|c|}{ Variance Proportions } \\
\hline & & & & (Constant) & Leverage & Equity \\
\hline \multirow{3}{*}{1} & 1 & 2.316 & 1.000 & .00 & .00 & .00 \\
\hline & 2 & .684 & 1.841 & .00 & .00 & .01 \\
\hline & 3 & .001 & 58.928 & 1.00 & 1.00 & .99 \\
\hline
\end{tabular}

a. Criterion Variable: ROA 
INTERNATIONAL JOURNAL OF ACADEMIC RESEARCH IN ACCOUNTING, FINANCE AND MANAGEMENT SCIENCES

Vol. 10 , No. 3, 2020, E-ISSN: 2225-8329 @ 2020 HRMARS

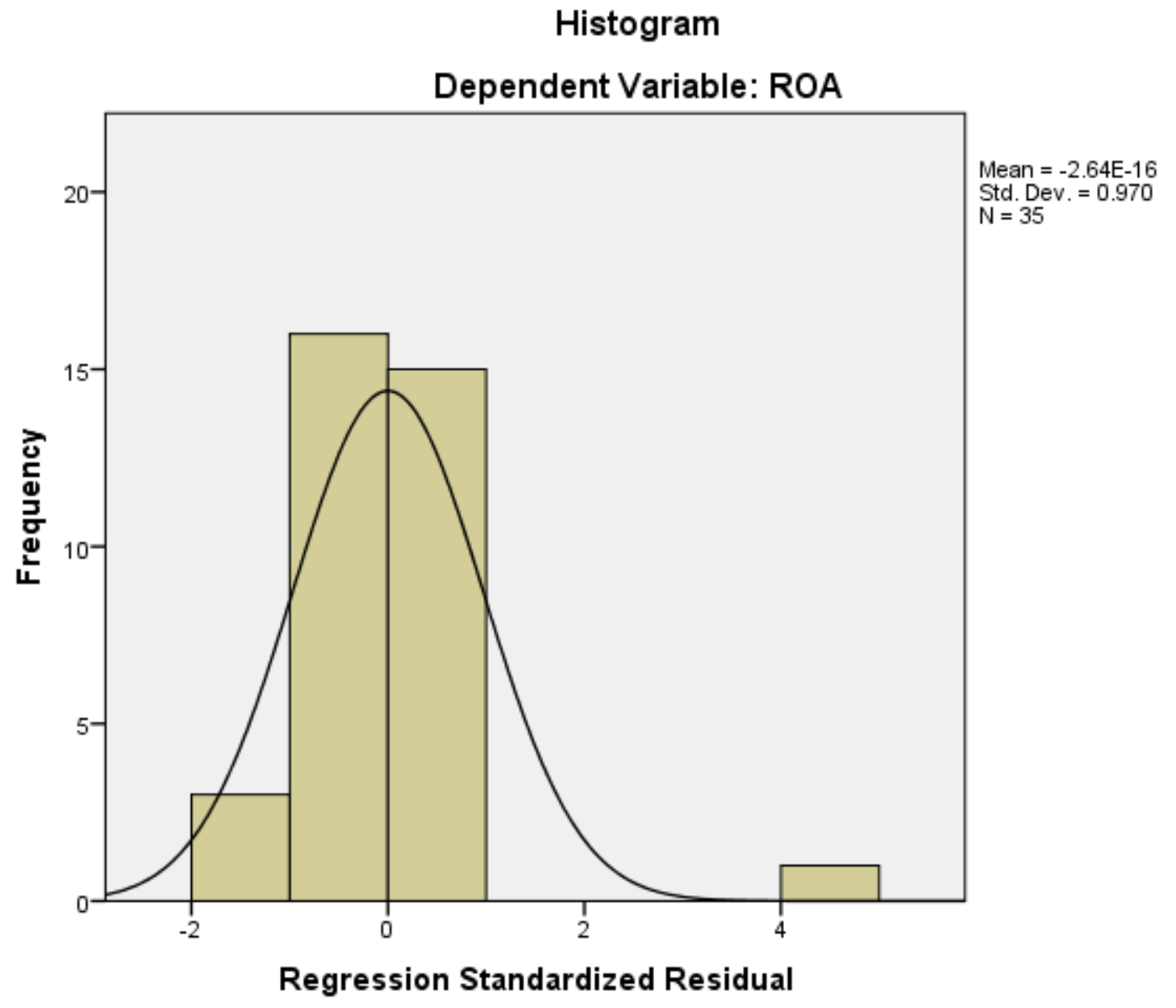


INTERNATIONAL JOURNAL OF ACADEMIC RESEARCH IN ACCOUNTING, FINANCE AND MANAGEMENT SCIENCES

Vol. 10 , No. 3, 2020, E-ISSN: 2225-8329 @ 2020 HRMARS

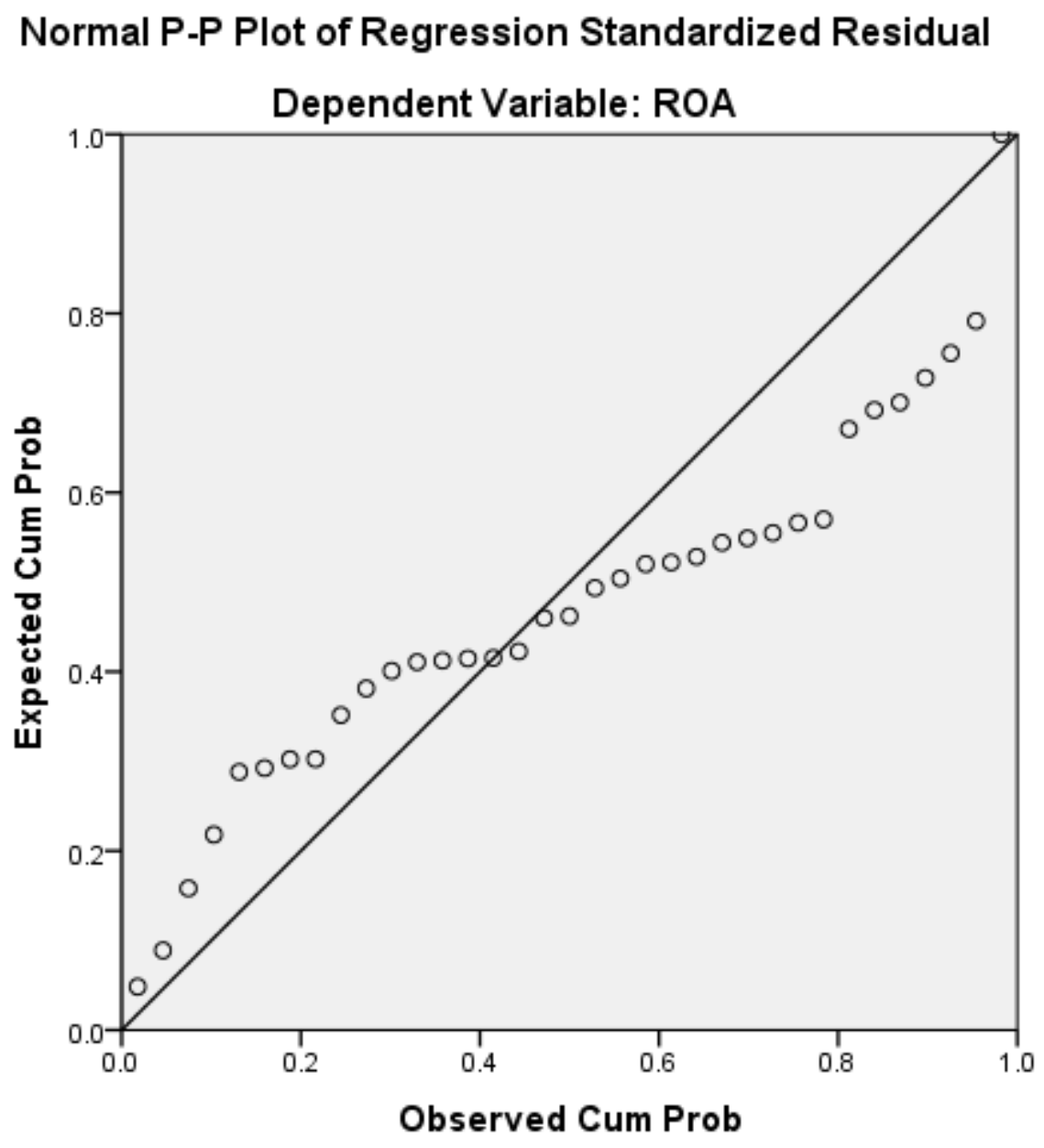

